\title{
Determinants of the medium of payment used to acquire privately-held targets
}

\author{
Jeff Madura $\cdot$ Thanh Ngo
}

Published online: 15 April 2010

(C) The Author(s) 2010. This article is published with open access at Springerlink.com

\begin{abstract}
Since private firms have a unique ownership structure, the method of payment decision when acquiring private firms is influenced by a different set of factors than the method of payment decision when acquiring public firms. We find that bidders are more likely to pay for private targets with stock when the capital gain tax rate is relatively high. This relationship is attributed to greater tax benefits to private owners who receive stock in periods when the capital gains tax is high. Bidders are more likely to use stock in takeovers when the targets are high-tech firms, which we attribute to protection against overpayment by using a contingent pricing method. Bidders are more likely to use cash in takeovers since the Sarbanes-Oxley Act, which we attribute to the higher level of due diligence by bidder managers and board members, and therefore a reduced need for contingent pricing methods like stock. Overall, the results suggest the likelihood of using stock to acquire private targets is positively related to the information asymmetry between the parties, while the likelihood of using cash is greater when conditions (such as SOX) reduce the information asymmetry.
\end{abstract}

Keywords Mergers and Acquisitions · Privately-Held Targets · Payment Methods

\section{JEL Classification G34 · G14}

\section{Introduction}

When a public firm plans to acquire a target, it can use cash, stock, some other forms of payment, or a combination. What factors drive its decision regarding the method of payment? This question has been thoroughly addressed by studies that assess

\footnotetext{
J. Madura

Florida Atlantic University, Boca Raton, FL, USA

e-mail: jeffmadura@bellsouth.net

T. Ngo $(\bowtie)$

The University of Texas-Pan American, Edinburg, TX, USA

e-mail: ngotn@utpa.edu
} 
takeovers of publicly-traded targets. Myers and Majluf (1984) and Loughran and Vijh (1997) suggest that bidders are more likely to use stock to pay for acquisitions when their stock is overvalued. Studies by Schleifer and Vishny (2003), Rhodes-Kropf and Viswanathan (2004), Rhodes-Kropt et al. (2005), and Dong et al. (2006) demonstrate empirically that bidders of public targets with overvalued stock are more likely to use stock as a method of payment.

Since the financing decision can affect the potential benefits of an acquisition, an understanding of the factors that affect the financing decision is relevant. The method of payment can influence the valuation of the participating firms, and therefore can affect the wealth of participating shareholders (see Wansley et al. 1983). Several studies (such as that of Martin 1996) have attempted to identify characteristics that influence how bidding firm finances a takeover. Yet, these studies tend to focus only on public targets, which exclude a large proportion of takeovers from the sample. Martin (1996) and Faccio and Masulis (2005) include private targets within their sample. However, these two studies do not attempt to explain why firms use cash versus stock when pursuing private targets. The choice of the method of payment for public bidders that pursue private targets can affect the benefits to the shareholders of the bidders and the owners of the target firms. Therefore, it is important to understand the characteristics that influence the choice of the method of payment.

Private targets are much different from public targets, so that the decision regarding method of payment may be driven by different factors. In particular, the ownership structure of private firms is unique. Each owner of private targets tends to hold a very large proportion of the targets' equity, and that investment typically represents a large proportion of their total wealth. Thus, owners of private targets are more likely to closely scrutinize the value of a bidder that offers a stock payment. Conversely, shareholders of public targets typically hold a relatively small proportion of the targets' equity and their investment is normally a small proportion of their total wealth. Therefore, these shareholders do not have the same incentive to scrutinize the bidder stock value. Most individual shareholders could not control any part of the deal (including the medium of payment) even if they were against it. Another unique feature of the private targets is that when they are acquired with stock, their owners commonly become blockholders who can effectively monitor the bidders and reduce the possible agency problems in the bidding firms (see Chang 1998 for more details about the difference between private and public firm ownership).

Given the unique characteristics of a private firm, the conclusions of studies regarding the factors that affect financing decisions when acquiring public targets do not necessarily apply to the acquisitions of private targets. Our goal is to identify the characteristics that influence a bidder's decision to use cash versus stock or a combination of cash and stock when acquiring private targets. We find that bidders are more likely to pay for private targets with stock when the capital gain tax rate is relatively high. This relationship is attributed to greater tax benefits to private owners who receive stock in periods when the capital gains tax is high. Bidders are more likely to use stock in takeovers when the targets are high-tech firms, which tend to exhibit a higher degree of asymmetric information. Therefore, we attribute this result to protection against overpayment by using a contingent pricing method. We also find that the likelihood of using stock to acquire private targets has declined since the SarbanesOxley Act, which we attribute to the higher level of due diligence by bidder managers 
and board members, a reduced likelihood that bidders can capitalize on using overvalued stock, and a reduced reliance on contingent pricing methods like stock. Overall, the results suggest the likelihood of using stock to acquire private targets is positively related to the information asymmetry between the parties.

\section{Hypotheses on factors that affect the method of payment}

To achieve our goal of determining why bidders select cash, stock, or a combination when acquiring a private target we identify several factors here that could have an influence on the method of payment selected.

\subsection{Effect of capital gain tax rate}

The Internal Revenue Code specifies how the proceeds received by target shareholders are taxed. As explained by Ayers et al. (2004), the taxability of proceeds is dependent on the medium of payment. Cash payments are subject to a capital gains tax, while stock payments qualify for indefinite deferral. The tax advantage of stock might cause a difference in the target shareholder's preference of cash versus stock. Wansley et al. (1983) find that the target experiences a larger abnormal return when receiving payment in cash as opposed to stock. They attribute the difference to the impact of taxation; the target shareholders in cash deals should obtain higher returns to offset their immediate gain realization. Ayers et al. (2003) support Wansley, Lane and Yang's argument with their findings that acquisition premiums in taxable acquisitions increase with shareholder capital gain taxes. Tax can be considered an incremental cost in taxable deals.

Ayers et al. (2004) determine that the propensity to use stock financing is greater when capital gains taxes are high. However, their study focuses only on public targets, which have a greater proportion of institutional ownership. Stock financing should be even more desirable for private target shareholders when capital gains taxes are high, because most private target shareholders are subject to capital gains taxes (unlike institutional investors). The use of stock by the bidder allows the private target owners to defer the capital gain, which is especially beneficial when the capital gain tax rate is relatively high.

However, the uniqueness of private target ownership also offers a counter hypothesis. By accepting stock and therefore deferring their gains, there is uncertainty surrounding the future value of proceeds that the private target shareholders will ultimately receive. In fact, Loughran and Vijh (1997) offer strong evidence that shareholders of publiclytraded targets who held on to bidder stock for long periods of time experieced major losses on those holdings. However, Chang (1998) found that the performance of bidder stock has been high when used to acquire private targets, as the private targets owners may become strong monitors of the bidder.

Given that the owners of private targets may have a large amount of their wealth tied up in these proceeds, they must weigh the advantage of the tax benefit from stock payment against the risk associated with the future value of the stock proceeds when sold. To the extent that the uncertainty offsets the tax advantage, the prevailing capital gains rate may not influence the medium of payment. 
We use the maximum capital gain tax rate in the year (see Ayers et al. 2004) of the takeover of concern (MAXTAX), which ranged from $15 \%$ to $28 \%$ during the sample period. Given that the private targets owners are likely to be categorized in high tax brackets at the time that they are subject to capital gains taxes, we use the maximum capital gains tax as our proxy.

\subsection{Effect of relative size}

Private firms are subject to limited disclosure and monitoring by market participants. Thus, there is extensive information asymmetry between the bidder and the target in a takeover of a privately-held target (Officer et al. 2006). The risk of bidder overpayment is a greater concern when pursuing larger private targets because of the larger potential adverse impact due to overpayment. Since stock has a contingent pricing effect that makes the target share the risk of misvaluation with the bidder, the probability of stock being used as a payment method should be higher when the deal value is relatively large compared to the bidding firm's size. We calculate the relative size ratio as the ratio of the dollar value of the deal to the market value of the bidder 4 weeks prior to the announcement date.

\subsection{Effect of high-tech targets}

According to Kohers and Kohers (2000), the values of high-tech firms are dependent on outcomes of research and development projects. There is much uncertainty surrounding the value of a high tech firm, which increases the potential loss from overpayment by bidders. Thus, bidders should prefer to use stock (instead of cash) when acquiring a high-tech private target, so that target shareholders share the risk that the bidder overvalues the target firm.

Houston and Ryngaert (1997) confirm that stock helps reduce the "lemon" problems concerning the target's value. The argument is also employed by a more recent study by Officer et al. (2006) to explain the bidder returns in takeovers of privately-held firms. We apply a dummy variable set equal to 1.0 for high-tech firms and zero otherwise, based on the classification of high-tech firms by the SDC.

\subsection{Effect of the Sarbanes-Oxley act}

The Sarbanes-Oxley Act (SOX) introduced in July 2002 requires stringent financial reporting requirements among firms, and some of its provisions have direct bearing on the assessment of potential targets. Specifically, bidders must closely examine the target's internal controls, financial reporting, and procedures. SOX mandates that bidders assess financial, tax, and legal implications of a merger. ${ }^{1}$ In addition, the boards of directors are required to document their oversight of key transactions such as mergers, and certify that such transactions are warranted. ${ }^{2}$

\footnotetext{
${ }^{1}$ See "Sarbanes Jitters Force Buyers to Intensify Due Diligence" by M. Sikora, Mergers and Acquisitions, 38, April 2003, p.9.

2 See "Is M\&A the Only Way to Top-Line Growth?", by F. Hansen, Business Finance, 10, November 2004, p. 24.
} 
SOX may also prevent takeovers that are motivated to hide existing expenses. Section 302 of SOX requires chief executives and financial officers of public companies to take responsibility for the accuracy of consolidated financial statements resulting from takeovers. Overall, SOX forces managers and boards to justify their takeover decisions and to be more accountable. Dong et al. (2006) suggest that bidders tend to use stock as payment for targets when they are more overvalued. To the extent that SOX increases transparency and reduces the potential degree of overvaluation, it may discourage bidders from using stock as their method of payment. Furthermore, bidders may be more willing to use cash to pursue a privately-held target since SOX if their more serious assessment reduces the risk of misvaluing the target. We use a dummy variable to categorize whether the takeover occurred before or after SOX, which is set equal to 1 for takeovers after July 30th 2002 when the SOX bill was adopted and 0 otherwise.

\subsection{Effect of the bidding firm's block ownership structure}

Due to the highly-concentrated ownership structure of privately-held firms, takeovers of privately-held firms with stock will likely result in new blockholders, and the likelihood is much higher among takeovers of private firms as compared to takeovers of public firms. The use of stock as a payment medium can create new blockholders, threatening the existing control positions of the bidders' big shareholders. Therefore, bidders with more concentrated ownership tend to use cash to protect the controlling power (Stulz 1988; Amihud et al. 1990; Jung et al. 1996; Martin 1996; Ghosh and Ruland 1998; Faccio and Masulis 2005). While most previous studies focus on the relation between the bidding firm's ownership concentration and the choice of payment medium among takeovers of public targets, the relation is expected to be much more pronounced among takeovers of privatelyheld targets.

We obtain ownership data of the bidding firm in the fiscal year preceding the announcement date from Wharton Research database for the sample period of 19962002 and from the proxy statements for the remaining sample period. We use a variable NUMBLOCK, defined as the total number of blockholders in the bidding firm. We also consider an alternative proxy SUMBLOCK, which is measured as the sum of all blockholder shares as a percentage of total shares outstanding. We expect that NUMBLOCK and SUMBLOCK are inversely related to the probability of stock being used as a payment form. ${ }^{3}$

\subsection{Effect of target owner involvement in the combined entity}

Owners of the privately-held targets will only be willing to receive the bidders' stock if they want to continue their investments in the combined entity. They may be more willing to accept stock when they are retained as managers or board members of the combined entity. Ghosh and Ruland (1998) find that managers of the target firm are more likely to retain jobs when the takeover is paid with stock instead of cash.

\footnotetext{
${ }^{3}$ A blockholder is defined as owning at least $5 \%$ of outstanding shares. We also consider an alternative proxy, which is the sum of the percentage of the bidding firm's outstanding shares held by blockholders.
} 
However, their finding applies only to a sample of takeovers of publicly-traded targets. We include a dummy variable set equal to 1.0 when the target owner becomes the manager or joins the board of directors of the combined entity. Data on this variable are obtained from the $8 \mathrm{~K}$ forms that the bidding firm files with the SEC upon / after the takeover announcement date. The data can only be obtained from takeovers during the period 2000-2005.

\subsection{Inclusion of control variables}

In addition to the above hypothesized relationships, we also control for other factors which have been applied to takeovers of publicly-traded targets.

Relatedness in the bidders' and the targets' businesses Faccio and Masulis (2005) argue that targets are more likely to accept stock as a continuing investment in related takeovers because they are well acquainted with the bidders' business risks and growth potential. This should especially apply to private targets, since much of their wealth may be tied to the proceeds received from a takeover. Thus, the probability of stock being used for payment is highest when the bidders are in the same industry as the targets. However, a counter argument is that a bidder is more willing to use cash in related acquisitions because the degree of asymmetric information is lower.

Pre-takeover level of free cash flows Cash rich firms tend to prefer cash-financed mergers rather than stock-financed mergers (Martin 1996; Harford 1999).

Pre-takeover leverage level If firms use a mix of capital that optimizes their capital structure, or is at least within an acceptable range, their future financing decisions (including the merger financing decision) could be influenced by their existing capital structure. For example, if bidders could be subject to a debt capacity due to taking advantage of low interest rates. Bidders with a high level of outstanding debt might be more likely to use stock to pay for takeovers because they may be unable to issue new debt or borrow more from banks to finance the deals (Faccio and Masulis 2005), and because they want to increase the debt capacity of the combined entity (Travlos 1987).

\section{Data}

We rely on the Securities Data Corporation (SDC) Platinum Mergers and Acquisitions Database to compile our sample. First, we identify completed takeovers of privately-held targets by publicly-traded bidders from 1985 to 2005 . The initial sample includes 5,296 takeovers. Then we impose the restriction that the deal value must be at least $10 \%$ of the bidder's market value in order to focus on takeovers that could have a major impact on the bidder. This screen reduces the sample size to 1,533 observations. The takeovers must be completed transactions by publiclytraded bidders whose stocks are traded on AMEX, NYSE or Nasdaq. We require that the time to complete the deal (the time length from the announcement date to the 
effective date) should be less than or equal to 2 years. The screening process described above results in a final sample of 1,418 completed takeovers of privatelyheld targets.

\section{Methodology}

To test the hypotheses, we employ two dependent variables of interest, (i) a dummy variable STOCK and (ii) a continuous variable PCTSTOCK. Following Fuller et al. (2002), we classify the payment methods into three 3 categories: (i) CASH, which includes cash payment, liabilities and debt, (ii) STOCK, which includes stock payment, earn-outs, warrants, options, rights, preferred stock, convertible debt and convertible preferred stock, and (iii) COMBO, a combination of cash and stock. Cash, liabilities, and debt are classified in the same category because the bidding firm has to pay immediate money out of pocket. Stock payment, earn-outs, warrants, options, rights, preferred stock, convertible debt and convertible preferred stock are classified in the same category because the payments are not immediate cash outflows to the combination.

The dummy variable STOCK takes on the value of 0 for CASH deals, 1 for COMBO deals and 2 for STOCK deals. We test this dependent variable STOCK using multinomial logistic regression models. In addition, we also use a continuous variable PCTSTOCK which is the percentage of the dollar value of payment in stock of the dollar value of a deal, and use ordinary least square regressions of this variable to examine which factors affect the amount of stock being used in the payment package.

To test for the hypotheses, we employ both multinomial logistic regressions and ordinary least squared regressions.

The final models to test are as follows:

$$
\begin{aligned}
\text { STOCK }= & \alpha_{i}+\beta_{1} \text { MAXTAX }+\beta_{2} \text { RELSIZE }+\beta_{3} \text { HITECH }+\beta_{4} S O X+\beta_{5} \text { NUMBLOCK } \\
& +\beta_{6} \text { RETAIN }+\beta_{7} \text { RELATED }+\beta_{8} F C F+\beta_{9} L E V E R+\varepsilon_{i}
\end{aligned}
$$

The dependent variable for the multinomial logistic regression above is STOCK which takes the value of 0 for cash deals, 1 for a combination of cash and stock, and 2 for stock takeovers.

$$
\begin{aligned}
\text { PCTSTOCK }= & \alpha_{i}+\beta_{1} \text { MAXTAX }+\beta_{2} \text { RELSIZE }+\beta_{3} \text { HITECH }+\beta_{4} \text { SOX }+\beta_{5} \text { NUMBLOCK } \\
& +\beta_{6} \text { RETAIN }+\beta_{7} \text { RELATED }+\beta_{8} \text { FCF }+\beta_{9} L E V E R+\varepsilon_{i}
\end{aligned}
$$

The dependent variable for the ordinary least squared regression above is PCTSTOCK which is the percentage of the dollar value of payment in stock of the dollar value of a deal. The multinomial logit model is applied when the dependent variable (form of payment) is classified into one of three alternative categories (cash, stock, or mixed). Therefore, this method is intended to explain the factors that cause a firm to select any one of those alternatives. Martin (1996) used this procedure to explain why firms use one of those forms of financing. Conversely, the ordinary least squares regression model is used when the form of payment is not classified 
into categories. Instead, the precise percentage of financing that is derived by providing stock is used. If for example, firm A used 50\% stock for financing its takeover, while firm B used 70\% stock for financing its takeover, the dependent variable would reflect these percentages. However, when categories are used, both of these takeovers would be categorized as mixed financing. The multinormial logic model is more appropriate when trying to explain why financing falls into one of three categories, while the OLS regression model is more appropriate when attempting to explain variation among the percentage of stock used (even when the percentages are within the same category).

The independent variables of interest are:

- MAXTAX is the maximum capital gain tax rate in each sample year.

- RELSIZE is the ratio of the deal value to the bidder's market value prior to the takeover announcement.

- $\mathrm{HITECH}=1$ if the target is a high-tech firm and 0 otherwise.

- $\operatorname{SOX}=1$ for takeovers taking place after July 30th 2002, and 0 otherwise.

- $\mathrm{NUMBLOCK}=$ the total number of blockholders in the bidding firms in the fiscal year preceding the announcement date. An alternative proxy SUMBLOCK is also tested, and is measured as the sum of all blockholder shares as a percentage of total shares outstanding.

- RETAIN $=1$ if the target owners are retained in the combined entity as either managers or members of director board, and 0 otherwise. Data are available for this variable in 514 acquisitions.

- RELATED $=1$ for takeovers in which the bidder's 2-digit SIC code is the same as that of the targets.

- FCF is the bidder's free cash flow per share in the fiscal year end prior to the announcement date.

- LEVER is the bidder's industry-adjusted debt-to-asset ratio in the fiscal year end prior to the announcement date.

\section{Results}

\subsection{Sample descriptive statistics}

The sample distribution by the sample years is provided in Table 1 . About $60 \%$ of the sample observations are clustered around the period 1995-2000 since this is the period of the most active takeover market for private targets. We break down the payment methods into: CASH (cash, liabilities and debt), STOCK (stock, earn-outs, warrants, options, preferred stock, convertible preferred stock and convertible debt), and COMBO (a combination of CASH and STOCK). Forty-eight percent of the takeovers in the sample are financed only with stock only, while $23 \%$ are financed with cash only. The remaining takeovers involve a combination of cash and stock payment. The number of stock-only takeovers peaked in the 1995-2000 period. Since 2003 , the number of cash-only takeover increased substantially.

Table 2 provides some descriptive statistics of the sample. Fifty-two percent of the sample deals involve high-tech targets, while $61 \%$ of the sample reflects 
Table 1 Sample distribution by year

\begin{tabular}{|c|c|c|c|c|c|}
\hline \multirow[t]{2}{*}{ Year } & \multicolumn{2}{|c|}{ Whole Sample } & \multirow[t]{2}{*}{ Cash Only } & \multirow[t]{2}{*}{ Stock Only } & \multirow[t]{2}{*}{ Combo } \\
\hline & $\mathrm{N}$ & $\%$ & & & \\
\hline 1985 & 4 & $0.28 \%$ & 1 & 3 & 0 \\
\hline 1986 & 14 & $0.99 \%$ & 4 & 8 & 2 \\
\hline 1987 & 7 & $0.49 \%$ & 2 & 4 & 1 \\
\hline 1988 & 6 & $0.42 \%$ & 5 & 0 & 1 \\
\hline 1989 & 9 & $0.63 \%$ & 2 & 4 & 3 \\
\hline 1990 & 8 & $0.56 \%$ & 4 & 2 & 2 \\
\hline 1991 & 42 & $2.96 \%$ & 3 & 21 & 18 \\
\hline 1992 & 45 & $3.17 \%$ & 7 & 28 & 10 \\
\hline 1993 & 36 & $2.54 \%$ & 12 & 17 & 7 \\
\hline 1994 & 69 & $4.87 \%$ & 18 & 36 & 15 \\
\hline 1995 & 103 & $7.26 \%$ & 28 & 55 & 20 \\
\hline 1996 & 109 & $7.69 \%$ & 19 & 70 & 20 \\
\hline 1997 & 130 & $9.17 \%$ & 21 & 78 & 31 \\
\hline 1998 & 167 & $11.78 \%$ & 26 & 90 & 51 \\
\hline 1999 & 131 & $9.24 \%$ & 10 & 89 & 32 \\
\hline 2000 & 196 & $13.82 \%$ & 22 & 119 & 55 \\
\hline 2001 & 61 & $4.30 \%$ & 18 & 20 & 23 \\
\hline 2002 & 37 & $2.61 \%$ & 11 & 5 & 21 \\
\hline 2003 & 67 & $4.72 \%$ & 27 & 14 & 26 \\
\hline 2004 & 81 & $5.71 \%$ & 40 & 9 & 32 \\
\hline 2005 & 96 & $6.77 \%$ & 44 & 10 & 42 \\
\hline Total & 1,418 & $100.00 \%$ & 324 & 682 & 412 \\
\hline
\end{tabular}

The sample distribution by year is provided in this table. The first column shows the number and the percentage of sample observations in each of the sample year. The next columns show the number of sample observations by the payment methods in each of the sample year

The payment methods are classified as:

(i) cash only,

(ii) stock only,

(iii) a combination of cash and stock (combo)

takeovers in related businesses based upon the 2-digit SIC codes. The deal value is about $\$ 121$ million on average.

5.2 Univariate comparisons between takeovers of different payment methods

Table 3 reports the frequency distribution of payment methods CASH, STOCK and COMBO. The samples are classified into subsamples based upon 4 criteria that are identified in the first column of Table 3: (i) whether the target is a high-tech firm, (ii) whether the takeover occurs before or after the adoption of the Sarbanes-Oxley Act, (iii) whether the takeover involves parties in related businesses, and (iv) whether the 
Table 2 Sample descriptive statistics

Panel A-\# of Observations and \% by Each Panel B-Some Key Characteristics Criteria

\begin{tabular}{|c|c|c|c|c|c|c|}
\hline \multicolumn{3}{|c|}{ Target is a high-tech firm. } & Variables & $\mathrm{N}$ & Mean & t-statistics \\
\hline Yes & 735 & $51.80 \%$ & Relative size ratio & 1,418 & 0.31 & 4.52 \\
\hline No & 683 & $48.20 \%$ & Deal value (\$ mil) & 1,418 & 121.97 & 13.64 \\
\hline \multicolumn{3}{|c|}{ Business-related takeovers } & Bidder's market value & 1,418 & $1,908.37$ & 7.83 \\
\hline Yes & 870 & $61.40 \%$ & Target's total asset (\$ mil) & 403 & 69.99 & 6.28 \\
\hline No & 548 & $38.60 \%$ & & & & \\
\hline
\end{tabular}

This table provides the descriptive statistics of some key characteristics of the sample. Panel A describes the number of observations and the percentage by four different criteria. Panel B provides the number of observations, the mean and the t-statistics for some key variables. Relative size ratio is the ratio of the deal value to the bidding firm market value in the four weeks prior to the announcement date. The bidding firm market value and the target firm total asset are obtained in the four weeks prior to the announcement date of the takeover. Data on these variables are obtained from SDC. *,**, *** and **** indicate the significance level at $10 \%, 5 \%, 1 \%$ and $0.1 \%$, respectively

target management is retained after the takeover. In addition, for the COMBO payment, we also report the dollar value of cash and stock, separately, as percentages of the deal value.

For takeovers of low-tech targets, there is no significant difference in the frequency of the payment methods. Cash is used in about $30 \%$ of the takeovers of low-tech targets; stock is used in 38\% of the deals, and a combination of cash and stock is used in $32 \%$ of the deals. However, for takeovers of high-tech targets, the use of stock is more frequent than cash. Stock is used in $57 \%$ of takeovers of hightech targets while cash is used in only $16 \%$ of the deals. In addition, within the COMBO payment method, the dollar value of stock as a percentage of the deal value is much higher among takeovers of high-tech targets than among takeovers of lowtech targets $(57 \%$ as compared to $45 \%)$.

The percentage of cash takeovers in the post-SOX period is more than twice that in the pre-SOX period ( $44 \%$ as compared to $18 \%$ ). Furthermore, the percentage of stock-financed takeovers is $56 \%$ before SOX versus only $14 \%$ after SOX. These results offer strong support for our hypothesis that stock financed mergers should have been reduced in favor of cash transactions since SOX. We attribute these results to the greater transparency since SOX, which may reduce the ability of bidders to capitalize on misvaluation, and may also make bidders more willing to back their takeover with cash if they exercise proper due diligence.

A comparison between takeovers of business-related parties and among takeovers of business-unrelated parties show no significant difference in the frequency of the payment methods between the two subsamples of takeovers. Data on whether the target management is retained in the combined entity after the takeover are only available for 514 takeovers in the period 2000-2005. There is no significant difference in the frequently of the payment methods between the subsamples in which the target management is or is not retained in the combined entity.

Table 4 compares the dollar value of cash and stock as percentages of the deal value for each subsample using both the traditional t-test and the non-parametric 
Table 3 Distribution of payment methods by some classification

\begin{tabular}{|c|c|c|c|c|c|c|c|c|c|}
\hline \multirow[t]{2}{*}{ Groups } & \multirow{2}{*}{$\begin{array}{l}\text { Total \# of } \\
\text { Observations }\end{array}$} & \multicolumn{2}{|c|}{$\mathrm{CASH}$} & \multicolumn{2}{|c|}{ STOCK } & \multicolumn{4}{|c|}{ COMBO } \\
\hline & & $\mathrm{N}$ & Percent & $\mathrm{N}$ & Percent & $\mathrm{N}$ & Percent & $\begin{array}{l}\% \text { Stock } \\
\text { Value }\end{array}$ & $\begin{array}{l}\% \text { Cash } \\
\text { Value }\end{array}$ \\
\hline Low-tech targets & 683 & 204 & $29.87 \%$ & 260 & $38.07 \%$ & 219 & $32.06 \%$ & $44.92 \%$ & $55.08 \%$ \\
\hline High-tech targets & 735 & 120 & $16.33 \%$ & 422 & $57.41 \%$ & 193 & $26.26 \%$ & $57.58 \%$ & $42.42 \%$ \\
\hline Total & 1,418 & & & & & & & & \\
\hline Takeovers before SOX & 1,161 & 210 & $18.09 \%$ & 646 & $55.64 \%$ & 305 & $26.27 \%$ & $53.52 \%$ & $46.48 \%$ \\
\hline Takeovers after SOX & 257 & 114 & $44.36 \%$ & 36 & $14.01 \%$ & 107 & $41.63 \%$ & $43.28 \%$ & $56.72 \%$ \\
\hline Total & 1,418 & & & & & & & & \\
\hline Non-related takeovers & 548 & 124 & $22.63 \%$ & 251 & $45.80 \%$ & 173 & $31.57 \%$ & $48.82 \%$ & $51.18 \%$ \\
\hline Related takeovers & 870 & 200 & $22.99 \%$ & 431 & $49.54 \%$ & 239 & $27.47 \%$ & $52.33 \%$ & $47.67 \%$ \\
\hline Total & 1,418 & & & & & & & & \\
\hline Mgmt is not retained & 233 & 73 & $31.33 \%$ & 56 & $24.03 \%$ & 104 & $44.64 \%$ & $49.44 \%$ & $50.56 \%$ \\
\hline Mgmt is retained & 281 & 92 & $32.74 \%$ & 59 & $21.00 \%$ & 127 & $45.20 \%$ & $44.79 \%$ & $55.21 \%$ \\
\hline Total & 514 & & & & & & & & \\
\hline
\end{tabular}

This table provides the number of observations of the following three forms of payment by four different classifications. The three forms of payment examined include (i) cash, (ii) stock, and (iii) a combination of cash and stock. The number of observations of each of the three payment forms is compared between (i) takeovers of high-tech targets versus takeovers of low-tech targets, (ii) takeovers before the SarbanesOxley Act adoption and takeovers after the Sarbanes-Oxley Act (SOX), (iii) takeovers of business-related parties versus takeovers of business-unrelated parties, and (iv) takeovers in which target management is retained after the takeovers versus takeovers in which target management is not retained afterward. \% stock value, and \% cash value indicate the dollar value of stock and cash payment forms, respectively, as percentages of the deal value

Wilcoxon test. The cash percentage is significantly higher for takeovers of low-tech targets as compared to takeovers of high-tech targets. The stock percentage is significantly lower for takeovers of low-tech targets as compared to takeovers of hightech targets. The results support the argument that stock is used to a greater extent among takeovers of high-tech targets to protect the bidding firm, which may be attributed to bidders protecting against the risk of misvaluation of high-tech targets.

The cash percentage is significantly higher for takeovers after SOX as compared to takeovers before SOX, which is consistent with our hypothesis. The cash percentage is not significantly different between takeovers of business-related parties and takeovers of business-unrelated parties. The stock percentage is significantly higher among takeovers with retained target management than among takeovers without retained target management.

Table 5 provides some key deal characteristics between the three forms of payment, CASH, STOCK and COMBO. The last three columns of Table 5 compare the characteristics between the CASH and the STOCK subsamples using both the traditional t-test and the non-parametric Wilcoxon test. The MAXTAX variable is higher for takeovers financed with stock, which could be attributed to the motive of deferring the tax on the gain. The deal value, the bidding firm's market value and the relative size (e.g. the ratio of the deal value to the bidding firm's market value) of 
Table 4 Comparisons of the percentage of each payment method by some classification

\begin{tabular}{|c|c|c|c|c|c|c|c|c|c|}
\hline \multirow[b]{2}{*}{ Variable } & \multicolumn{3}{|c|}{ Low-tech Targets } & \multicolumn{3}{|c|}{ High-tech Targets } & \multicolumn{3}{|l|}{ Difference } \\
\hline & $\mathrm{N}$ & Mean & t-stat & $\mathrm{N}$ & Mean & t-stat & Mean & t-stat & Wilcoxon test p-value \\
\hline$\%$ cash & 683 & $41.02 \%$ & 25.27 & 735 & $23.80 \%$ & 17.47 & $17.21 \%$ & 4.05 & $<0.0001$ \\
\hline \multirow[t]{2}{*}{$\%$ stock } & 683 & $58.99 \%$ & 36.34 & 735 & $76.20 \%$ & 55.91 & $-17.21 \%$ & -8.12 & $<0.0001$ \\
\hline & \multicolumn{3}{|c|}{ Pre-SOX } & \multicolumn{3}{|c|}{ Post-SOX } & \multicolumn{3}{|c|}{ Difference } \\
\hline Variable & $\mathrm{N}$ & Mean & t-stat & $\mathrm{N}$ & Mean & t-stat & Mean & t-stat & Wilcoxon test $\mathrm{p}$-value \\
\hline$\%$ cash & 1,161 & $25.68 \%$ & 23.0 & 257 & $61.09 \%$ & 25.02 & $-35.41 \%$ & -3.66 & 0.0008 \\
\hline \multirow[t]{2}{*}{$\%$ stock } & 1,161 & $74.32 \%$ & 66.59 & 257 & $38.91 \%$ & 15.94 & $35.41 \%$ & 13.19 & $<0.0001$ \\
\hline & \multicolumn{3}{|c|}{ Non-related Takeovers } & \multicolumn{3}{|c|}{ Related Takeovers } & \multicolumn{3}{|c|}{ Difference } \\
\hline Variable & $\mathrm{N}$ & Mean & t-stat & $\mathrm{N}$ & Mean & t-stat & Mean & t-stat & Wilcoxon test p-value \\
\hline$\%$ cash & 548 & $33.48 \%$ & 19.13 & 870 & $31.22 \%$ & 22.83 & $2.26 \%$ & 0.4 & 0.4 \\
\hline \multirow[t]{2}{*}{$\%$ stock } & 548 & $66.52 \%$ & 38.01 & 870 & $68.78 \%$ & 50.29 & $-2.26 \%$ & -1.02 & 0.36 \\
\hline & \multicolumn{3}{|c|}{$\begin{array}{l}\text { Target management } \\
\text { is not retained }\end{array}$} & \multicolumn{3}{|c|}{$\begin{array}{l}\text { Target management } \\
\text { is retained }\end{array}$} & \multicolumn{3}{|l|}{ Difference } \\
\hline Variable & $\mathrm{N}$ & Mean & t-stat & $\mathrm{N}$ & Mean & t-stat & Mean & t-stat & Wilcoxon test p-value \\
\hline$\%$ cash & 233 & $61.24 \%$ & 18.72 & 281 & $51.52 \%$ & 17.37 & $9.72 \%$ & 1.89 & 0.08 \\
\hline$\%$ stock & 233 & $38.76 \%$ & 11.85 & 281 & $48.48 \%$ & 16.35 & $-9.72 \%$ & -2.2 & 0.009 \\
\hline
\end{tabular}

This table compares the percentage of each payment method by four classifications. The percentage of each payment form is compared between:

(i) takeovers of high-tech targets versus takeovers of low-tech targets,

(ii) takeovers before the Sarbanes-Oxley Act adoption and takeovers after the Sarbanes-Oxley Act (SOX),

(iii) takeovers of business-related parties versus takeovers of business-unrelated parties, and

(iv) takeovers in which target management is retained after the takeovers versus takeovers in which target management is not retained afterward

stock takeovers is significantly larger than those of cash takeovers. These results support the hypothesis that stock is used to reduce the risk of misvaluation of the target for larger deals, or when the deal reflects a larger proportion of the bidder's market value. The mean number of blockholders in the bidding firm before a stock takeover is significantly larger (at the .10 level) than that before a cash takeover. ${ }^{4}$

\subsection{Multinomial logistic regressions}

Table 6 provides the results of the multinomial logistic analyses, whereby the dependent variable is STOCK which takes on the value of 0 for cash takeovers, 1 for takeovers paid with a combination of cash and stock/combo and 2 for stock takeovers. STOCK with the value of 2 is used as the reference group. Panel A indicates the comparison between the reference group (stock takeovers or STOCK $=2$ ) and the lowest category (cash takeovers or STOCK $=0$ ). Panel B provides the comparison

\footnotetext{
${ }^{4}$ We also tested an alternative proxy, the total percentage of the bidding firm shares held by blockholders in the fiscal year preceding the announcement date. We found that the percentage of the bidder's shares held by all blockholders before the takeover is not significantly different between cash takeovers and stock takeovers.
} 


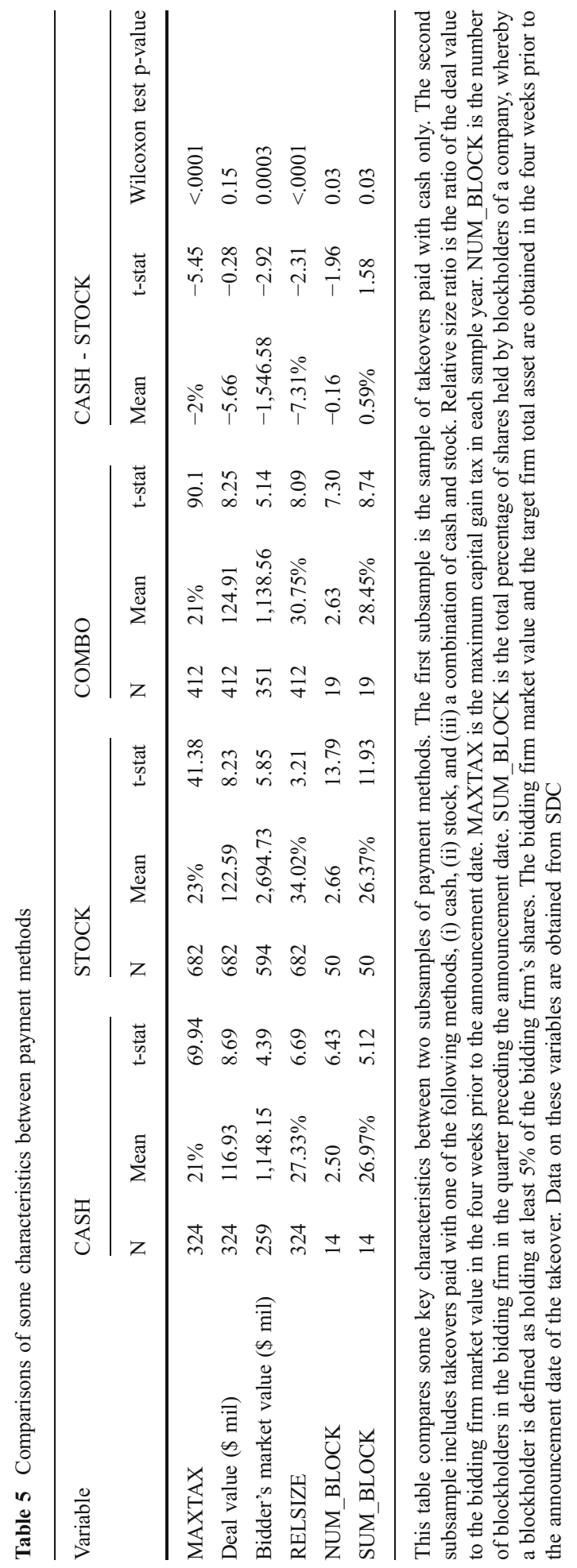


Table 6 Multinomial logistic regressions of payment choices

Panel A-Stock versus Cash

\begin{tabular}{|c|c|c|c|}
\hline & Model 1 & Model 2 & Model 3 \\
\hline Intercept & -0.07 & -0.05 & -5.63 \\
\hline MAXTAX & 0.97 & 0.92 & 25.24 \\
\hline RELSIZE & $0.65^{\mathrm{c}}$ & $0.65^{\mathrm{c}}$ & $0.22^{\mathrm{a}}$ \\
\hline HITECH & $1.26^{\mathrm{d}}$ & $1.26^{\mathrm{d}}$ & $0.72^{\mathrm{a}}$ \\
\hline SOX & $-2.68^{\mathrm{d}}$ & $-2.69^{\mathrm{d}}$ & -0.78 \\
\hline NUMBLOCK & 0.16 & & -0.88 \\
\hline SUMBLOCK & & 0.01 & \\
\hline RETAIN & & & $1.21^{\mathrm{c}}$ \\
\hline RELATED & -0.15 & -0.15 & -0.33 \\
\hline LEVER & $0.32^{\mathrm{c}}$ & $0.32^{\mathrm{c}}$ & 0.08 \\
\hline FCF & $-0.24^{\mathrm{c}}$ & $-0.24^{\mathrm{c}}$ & $-0.45^{\mathrm{c}}$ \\
\hline \multicolumn{4}{|c|}{ Panel B-Stock versus Combo } \\
\hline & Model 1 & Model 2 & Model 3 \\
\hline Intercept & $-1.82^{\mathrm{b}}$ & $-1.81^{\mathrm{b}}$ & -0.13 \\
\hline MAXTAX & $8.98^{\mathrm{c}}$ & $8.96^{\mathrm{c}}$ & -0.74 \\
\hline RELSIZE & $0.09^{\mathrm{a}}$ & $0.09^{\mathrm{a}}$ & 0.19 \\
\hline HITECH & $0.90^{\mathrm{d}}$ & $0.90^{\mathrm{d}}$ & 0.35 \\
\hline SOX & $-1.49^{\mathrm{d}}$ & $-1.49^{\mathrm{d}}$ & -0.98 \\
\hline NUMBLOCK & 0.14 & & 1.25 \\
\hline SUMBLOCK & & 0.01 & \\
\hline RETAIN & & & 0.33 \\
\hline RELATED & 0.11 & 0.12 & -0.20 \\
\hline LEVER & -0.07 & -0.07 & -0.89 \\
\hline $\mathrm{FCF}$ & -0.01 & -0.01 & $-0.14^{\mathrm{a}}$ \\
\hline \multicolumn{4}{|c|}{ Panel C-Model Fitness Statistics } \\
\hline & Model 1 & Model 2 & Model 3 \\
\hline Pseudo R-squared & 0.27 & 0.26 & 0.21 \\
\hline Likelihood ratio & $336.58^{d}$ & $335.76^{d}$ & $65.12^{\mathrm{d}}$ \\
\hline $\mathrm{N}$ & 1,270 & 1,270 & 514 \\
\hline
\end{tabular}

This table provides the multinomial logistic regressions of payment choices. The dependent variable is a dummy variable STOCK equal to 0 for cash takeovers, 1 for takeovers paid with a combination of cash and stock, and 2 for stock takeovers. The reference group is for STOCK $=2$. Panel A provides the comparison between cash takeovers versus stock takeovers. Panel B provides the comparison between a combination of stock and cash versus stock takeovers. The explanatory variables are described as follows. RELATED is a dummy variable equal to 1 if the bidding firm and the target have the same 2-digit SIC code and 0 otherwise. LEVER is the bidding firm's debt-to-asset ratio in the year preceding the announcement date. FCF is the bidding firm's free cash flow per share in the fiscal year preceding the announcement date. MAXTAX is the maximum capital gain tax rate in each sample year. RELSIZE is the ratio of the deal value to the bidding firm market value in the four weeks leading to the announcement date. HITECH is a dummy variable equal to 1 for takeovers of high-tech targets and 0 otherwise. SOX is a dummy variable equal to 1 more takeovers taken place after the adoption of the Sarbanes Oxley Act and 0 otherwise. SUMBLOCK is the total percentage of shares held by all blockholders of the bidding firm in the quarter preceding the announcement date, whereby a blockholder is defined as holding at least $5 \%$ of the bidding firm outstanding shares. NUMBLOCK is the number of blockholders in the bidding firm in the quarter preceding the announcement date. RETAIN is a dummy variable equal to 1 for takeovers in which the target management is retained after the completion of the takeovers and 0 otherwise. ${ }^{\mathrm{a}},{ }^{\mathrm{b}},{ }^{\mathrm{c}}$ and ${ }^{\mathrm{d}}$ indicate the significance level at $10 \%, 5 \%, 1 \%$ and $0.1 \%$, respectively 
between the reference group (stock takeovers or STOCK $=2$ ) and the second lowest category (combo or STOCK $=1$ ). The likelihood ratios are highly significant, which indicates goodness of fit. In addition, the pseudo R-squared is between $21 \%$ and $27 \%$ among all models. Our initial focus is on Models 1 and 2, since these models are applied to the entire sample and only differ in that each uses its own proxy for measuring blockholder presence of the bidder. We turn our attention to Model 3 results only after completing our discussion of results for Model 1 and 2, since Model 3 is used to include the RETAIN variable but is applied to a smaller sample due to data limitations.

The MAXTAX coefficient in the models is positive, but is not significant. However, it is positive and significant in the models that compare stock and combo. Thus, there is evidence to support the hypothesis that bidders of private targets are more likely to use all stock in periods when the capital gains tax rate is relatively high.

The RELSIZE coefficient is positive and significant in the models comparing stock and cash and in the models comparing stock and combo. These results support the hypothesis that bidders of private targets are more likely to use stock than cash or a combination when the size of the deal relative to the bidding firm's market value is high.

The HITECH coefficient is positive and significant in the models comparing stock versus cash, and in the models comparing stock versus combo. These results support the hypothesis that bidders of private targets are more likely to use stock than cash or combo when the bidding firm acquires a private high-tech target.

The SOX coefficient is negative and significant in the models that compare stock and cash. It is also negative in the models that compare stock and combo. These results support the hypothesis that bidders acquiring private targets are more likely to use cash since the Sarbanes-Oxley Act. Since SOX increases transparency and reduces the potential degree of overvaluation, it can discourage bidders from using stock as their method of payment. In addition, bidders should be more willing to use cash to pursue a privately-held target since SOX if their more serious assessment reduces the risk of misvaluing the target.

The blockholder variables (NUMBLOCK and SUMBLOCK) are not significant in the comparison between stock and cash and in the comparison between stock and combo suggesting that the bidder's pre-takeover ownership concentration does not significantly affect the choice of payment method when acquiring private targets.

The RELATED variable is insignificant, suggesting that relatedness between the bidder and target does not affect the choice of the payment method. The LEVER coefficient is positive and significant in the models comparing stock takeovers and the cash takeovers. These results offer some support for the hypothesis that bidders with a high level of leverage are more likely to use stock. In addition, the FCF coefficient is negative and significant for all models comparing takeovers financed with stock versus cash. These results support the hypothesis that bidders are more likely to use cash for their acquisitions of private firms when they have a relatively large level of free cash flow. However, the LEVER and FCF variables are not significant in the models that compare stock and combo.

Model 3 is distinguished from Models 1 and 2 in that it includes the RETAIN variable. However, data for RETAIN were only available for a limited number of observations. The RETAIN coefficient is positive and significant in the comparison between stock and cash, which reinforces the earlier evidence that stock is more likely to be used rather than cash when the private owners are hired by the bidder 
firm or placed on the bidder's board of directors. A similar result is found for takeovers of publicly-traded targets by Ghosh and Ruland (1998). The RETAIN variable is not significant in the comparision between stock and combo. Some of the other variables that are significant when we assess the entire sample (in Table 6) are not significant when we assess the results from testing Model 3. However, we rely on the results from Models 1 and 2 when testing these variables, because those models are applied to the entire sample. The only reason for considering the results of Model 3 is to assess the RETAIN variable, since that variable is not included in Models 1 and 2.

\subsection{Cross-sectional analyses of the percentage of stock in the deal value}

Table 7 provides the results of the cross-sectional analyses of the dollar value of stock used as payment for the target as a percentage of the deal value (PCTSTOCK).

Table 7 Cross-sectional analyses of the percentage of stock

\begin{tabular}{llll}
\hline & Model 1 & Model 2 & Model 3 \\
\hline Intercept & $0.63^{\mathrm{b}}$ & $0.62^{\mathrm{b}}$ & -0.07 \\
MAXTAX & 0.00 & 0.00 & 0.15 \\
RELSIZE & 0.03 & 0.03 & $0.14^{\mathrm{b}}$ \\
HITECH & $0.26^{\mathrm{d}}$ & $0.26^{\mathrm{d}}$ & $0.16^{\mathrm{c}}$ \\
SOX & $-0.37^{\mathrm{d}}$ & $-0.37^{\mathrm{d}}$ & $-0.11^{\mathrm{a}}$ \\
NUMBLOCK & 0.03 & & 0.03 \\
SUMBLOCK & & 0.02 & \\
RETAIN & & & $0.13^{\mathrm{b}}$ \\
RELATED & 0.00 & 0.00 & -0.02 \\
LEVER & 0.00 & 0.00 & 0.02 \\
FCF & $-0.03^{\mathrm{a}}$ & -0.03 & $-0.12^{\mathrm{b}}$ \\
F-statistics & $37.04^{\mathrm{d}}$ & $36.96^{\mathrm{d}}$ & $6.30^{\mathrm{d}}$ \\
Adj. R-squared & 0.19 & 0.19 & 0.12 \\
DW & 1.96 & 1.96 & 1.95 \\
$\mathrm{~N}$ & 1,270 & 1,270 & 514 \\
\hline
\end{tabular}

This table provides the cross-sectional analyses of the variation of the percentage of payment forms other than cash-only payment. The dependent variable is the dollar value of stock as a percentage of the deal value for each takeover as reported by SDC. The explanatory variables are described as follows. RELATED is a dummy variable equal to 1 if the bidding firm and the target have the same 2-digit SIC code and 0 otherwise. LEVER is the bidding firm's debt-to-asset ratio in the year preceding the announcement date. FCF is the bidding firm's free cash flow per share in the fiscal year preceding the announcement date. MAXTAX is the maximum capital gain tax rate in each sample year. RELSIZE is the ratio of the deal value to the bidding firm market value in the four weeks leading to the announcement date. HITECH is a dummy variable equal to 1 for takeovers of hightech targets and 0 otherwise. SOX is a dummy variable equal to 1 more takeovers taken place after the adoption of the Sarbanes Oxley Act and 0 otherwise. SUMBLOCK is the total percentage of shares held by all blockholders of the bidding firm in the quarter preceding the announcement date, whereby a blockholder is defined as holding at least $5 \%$ of the bidding firm outstanding shares. NUMBLOCK is the number of blockholders in the bidding firm in the quarter preceding the announcement date. RETAIN is a dummy variable equal to 1 for takeovers in which the target management is retained after the completion of the takeovers and 0 otherwise. $^{\mathrm{a}},{ }^{\mathrm{b}},{ }^{\mathrm{c}}$ and ${ }^{\mathrm{d}}$ indicate the significance level at $10 \%, 5 \%, 1 \%$ and $0.1 \%$, respectively. The significance level of the parameter estimates are based upon heteroskedasticity-consistent standard errors 
The average adjusted R-squared of the models is between $12 \%$ and $19 \%$ for all models. The F-statistics are highly significant.

The variable MAXTAX is not statistically significant, providing no evidence that the tax rate influences the percentage of payment in the form of stock when acquiring private targets. The RELSIZE coefficient is positive in all three models but only significant in one of the models, providing modest evidence that the percentage of stock used is greater in larger deals. The bidders have more to lose in these situations and stock has the contingent pricing effect.

The coefficient on HITECH is positive and highly significant in all models, which suggests that bidders use a higher percentage of stock when acquiring high-tech private targets. These results reinforce those produced by the multinomial logistic analysis. The coefficient of SOX is negative and significant in all models, suggesting that bidders are more likely to use a higher percentage of cash since the inception of SOX when acquiring private targets. These results are consistent with those produced by the multinomial logistic analysis.

The coefficient on RETAIN is positive and significant at the $5 \%$ level in the only model in which it is used, suggesting that as the target management is retained in the combined entity, a higher proportion of the payment is in the form of stock. This result is consistent with that found when comparing stock- versus cash-financed takeovers in Table 6.

The control variables RELATED and LEVER are not significant in any of the models. The FCF coefficient is negative and significant in two of the three models, which suggests a higher proportion of cash used by bidders that have a relatively high level of free cash flow. This result is consistent the evidence found in the multinomial logistic analysis.

\section{Summary}

Several studies explain characteristics that influence the choice of payment used to acquire public firms. However, those results do not necessarily apply to takeovers of private firms. Since private firms have a unique ownership structure, the method of payment decision when acquiring private firms is influenced by a different set of factors than the method of payment decision when acquiring public firms. We examine the choice of payment method categorized by cash, stock, or a combination in takeovers of private targets, using multinomial logistic regression analysis. We also explain the variation in the percentage of stock used among takeovers of private targets. Results are generally consistent between both types of analyses.

Most of our focus is on characteristics that could be especially relevant to the acquisition of private targets. We find some evidence that bidders are more likely to pay for private targets with stock when the capital gain tax rate is relatively high. This relationship is attributed to greater tax benefits to private owners who receive stock in periods when the capital gains tax is high.

Bidders are more likely to use stock in takeovers of private high-tech targets than in takeovers of private low-tech targets. Information asymmetry and uncertainty are more pronounced for private high-tech targets, which prompts the bidder to protect itself from the risk of misevaluation by acquiring a private high-tech target with 
stock. In addition, bidders are more likely to use stock when they retain target management, which we attribute to the ease at which payment with bidder stock can ensure that these managers have incentives to make decisions for the bidder that maximize bidder value.

We find no significant effect of the bidding firm's pre-takeover ownership concentration on the choice of payment method. This result is distinctly different from studies that focused on the medium of payment decision for public targets, perhaps because the private target owners typically have more at stake than public target owners, and will not accept the bidder's stock when it is overvalued.

We also find that since the passage of the Sarbanes-Oxley Act, bidders are more likely to use cash to acquire private targets. Since SOX requires more due diligence by bidder managers and board members, it may reduce the potential for bad decisions such as overpayment for a target, so that bidders are more willing to use cash as payment rather than contingent pricing methods like stock. Bidders with more debt and less free cash flow prior to the deal tend to use stock more frequently and to a greater extent than cash or a combination of cash and stock. Overall, the results suggest that the medium of payment selected when acquiring private targets is associated with information asymmetry. The greater the level of information asymmetry between the parties, the more likely that contingent pricing methods like stock are used. When information asymmetry is reduced by conditions (such as SOX), bidders are more willing to use cash.

Open Access This article is distributed under the terms of the Creative Commons Attribution Noncommercial License which permits any noncommercial use, distribution, and reproduction in any medium, provided the original author(s) and source are credited.

\section{References}

Amihud Y, Lev B, Travlos N (1990) Corporate control and the choice of investment financing: the case of corporate acquisitions. J Finance 45:603-616

Ayers B, Lefanowicz C, Robinson J (2003) Shareholder taxes in acquisition premiums: the effect of capital gains taxation. J Finance 58:2783-2801

Ayers B, Lefanowicz C, Robinson J (2004) The effect of shareholder-level capital gains taxes on acquisition structure. Account Rev 79:859-887

Chang S (1998) Takeovers of privately held targets, methods of payment, and bidder returns. J Finance 53:773-784

Dong M, Hirshleifer D, Richardson S, Teoh SH (2006) Does investor misvaluation drive the takeover market. J Finance 61:725-762

Faccio M, Masulis R (2005) The choice of payment method in European mergers and acquisitions. J Finance 60(3):1345-1388

Fuller K, Netter J, Stegemoller M (2002) What do returns to bidding firms tell us? Evidence from firms that make many acquisitions. J Finance 57:1763-1793

Ghosh A, Ruland W (1998) Managerial ownership, the method of payment for acquisitions, and executive job retention. J Finance 53:785-798

Harford J (1999) Corporate cash reserves and acquisitions. J Finance 54:1969-1997

Houston J, Ryngaert M (1997) Equity issuance and adverse selection: a direct test using conditional stock offers. J Finance 52:197-219

Jung K, Kim Y, Stulz R (1996) Timing, investment opportunities, managerial discretion and the security issue decision. J Financ Econ 42:159-185 
Kohers N, Kohers T (2000) The value creation potential of high-tech mergers. Financ Anal J 56:40-50 Loughran T, Vijh A (1997) Do long-term shareholders benefit from corporate acquisitions? J Finance 52:1765-1790

Martin K (1996) The method of payment in corporate acquisitions, investment opportunities and management ownership. J Finance 51:1227-1246

Myers S, Majluf N (1984) Corporate financing and investment decisions when firms have information that investors do not have. J Financ Econ 13:187-221

Officer M, Poulsen A, Stegemoller M (2006) Information asymmetry and bidder return, Available at SSRN: http://ssrn.com/abstract=851604

Rhodes-Kropt M, Robinson D, Viswanathan S (2005) Valuation waves and merger activity: the empirical evidence. J Financ Econ 77:561-603

Rhodes-Kropf M, Viswanathan S (2004) Market valuation and merger waves. J Finance LIX:2685-2718

Schleifer A, Vishny R (2003) Stock market driven acquisitions. J Financ Econ 70:259-311

Stulz R (1988) Managerial control of voting rights. J Financ Econ 20:25-54

Travlos N (1987) Corporate takeover bids, method of payment, and bidding firm's stocks returns. J Finance 42:943-963

Wansley J, Lane W, Yang H (1983) Abnormal returns to acquired firms by type of acquisitions and method of payment. Financ Manage 12:16-22 